\title{
The influence of the composts with the participation of municipal sewage sludge on the available forms of phosphorus in the soil as well as the yield of the seeds of spring rape
}

\author{
${ }^{1}$ Edward Krzywy, ${ }^{1}$ Ewa Krzywy-Gawrońska, ${ }^{2} J o ́ z e f a$ Krzywy, ${ }^{1}$ Izabela Gutowska \\ ${ }^{1}$ University Agricultural, Department of Environmental Chemistry, ul. Stowackiego 17, 71-434 Szczecin, Poland, \\ e-mail: chemrol@agro.ar.szczecin.pl \\ ${ }^{2}$ The West Pomeranian Agency of Restructuring and Modernization of Agriculture, Szczecin, Poland
}

\begin{abstract}
The field and laboratory experiment was carried on the brown incomplete soil of the complex of rye good. The obtained results in the yield experiment show that the composts with the participation of municipal sewage sludge increased essentially the yield of the seeds of spring rape in comparison with the control variant. Doubling of the doses of mineral nitric - potassium fertilization against the background of the composts did not have a significant influence on increasing the yield of the seeds of spring rape in comparison with the single doses. The composts with the participation of municipal sewage sludge in the field and laboratory experiment caused a significant increase of the content of the available forms of phosphorus in the soil. As time went by the distribution of the composts in the soil, the content of the available forms of phosphorus increased.
\end{abstract}

Keywords: compost, municipal sewage sludge, seeds yield, soil.

Presented at VII Conference Wasteless Technologies and Waste Management in Chemical Industry and Agriculture, Międzyzdroje, 12 - 15 June, 2007.

\section{INTRODUCTION}

There has been a visible reduction of the number of cattle and sheep in the agricultural holdings in Poland for a dozen or so years. This situation is connected with reducing the production of the natural fertilizers. In $1986-2005$ an average quantity of phosphorus with the mineral fertilizers, which were put into the soil, decreased by about $65 \%$ in comparison with the $1986-1990$ years. The doses of nitrogen decreased by about $34 \%$ and potassium by about $65 \%$, 12, 16. The doses of calcareous fertilizers were also clearly decreased. At present in Poland the participation of the very acid soil and acid soil exceeds $50 \%$ of the agriculture area. It is said that $76 \%$ of very light and light soil have acid and very acid soil $\mathrm{pH}$. Excessive acidifying of the soil involves retardation of phosphorus among other things. The replaceable forms of aluminium and three-valuable iron appear in the $\mathrm{pHKCl}$ soil under 5,5. These forms mix with the available forms of phosphorus and, then they are forming the available compounds for the plants ${ }^{5,7}$.

The obtained results of the experiment of Gosek ${ }^{6}$ show that the percentage participation of the soils, which have very high and high content of the available forms of phosphorus for the plants, decreased by about $9 \%$ in relation to 1973 1993. At the same time the percentage participation of the soils, which have very low and low content of the available forms of phosphorus for the plants, increased by about $9 \%$.

This situation prompted looking for new, cheaper and safe for the environmental sources of phosphorus for the plants. The possibility of the enrichment of the soils in phosphorus by applying different wastes $^{\mathbf{1 0}}$ were described in this study, which had been published in Scientific Work Issue 1017 of the Economic Academy in Wrockaw.

The aim of the study is the indication of the influence of composts with the participation of municipal sewage sludge on molding the contents of the available forms of phosphorus for the plants and on quantity of the yield of spring rape's seeds and also the content of the element that was examined in them.

\section{MATERIALS AND METHODS}

Realizing the aim of the study, two experiments were carried out. The first field experiment was carried out in 2000 - 2001. There was defined the impact of the composts with the participation of municipal sewage sludge after seven months of distribution in the piles on the quantity of the yield of spring rape's seeds, the amount of phosphorus in them and also the content of the available forms of phosphorus in the soil after the inning of the tested plant (the first experiment). The second experiment was carried out in 2003 -2004 . The aim of this experiment was defining the changes of the content of the available forms of phosphorus for the plants in the soil. This soil included the composts with the participation of municipal sewage sludge and potato pulp after seven months of the distribution in the plastic bin (the second experiment).

The content of the available forms of phosphorus for the plants in the soil was signified according to the Egner-Riehm's method. The remaining analyses of the soil and the tested plant were made according to the method of Ostrowska ${ }^{14}$ and Panak ${ }^{15}$.

\section{RESULTS}

The first vegetative - field experiment was carried in 2001 on a brown incomplete soil, the quality class IV a, the complex of agriculture usefulness 5 (rye good) and $\mathrm{pH}_{\mathrm{KCl}} 6,7$. This soil included $87,2 \mathrm{mg} \mathrm{P} \cdot \mathrm{kg}^{-1}$ d.m. and $135,5 \mathrm{mg} \mathrm{K} \cdot \mathrm{kg}^{-}$ ${ }^{1} \mathrm{~d}$.m. of the available forms for the plants. 7 variants of the soil, which had been fertilized with composts, were used in the pattern of the experiment (Table 1). The quantity of the composts' doses was established on the level of $200 \mathrm{~kg} \mathrm{~N} \cdot \mathrm{ha}^{-1}$. Two levels of the mineral nitric-potassium fertilization were additionally used for the sake of the small content of potassium 
in the composts $\left(6,0-7,8 \mathrm{~g} \mathrm{~K} \cdot \mathrm{kg}^{-1}\right.$ s.m. $)$ in relation to nitrogen $\left(23,8-35,8 \mathrm{~g} \mathrm{~N} \cdot \mathrm{kg}^{-1} \mathrm{~s} . \mathrm{m}\right.$.) and phosphorus (23,1 $-28,0 \mathrm{~g} \mathrm{P} \cdot \mathrm{kg}^{-1}$ s.m.), as well as according to Maćkowiak ${ }^{13} \mathrm{a}$ low utilization of nitrogen from municipal sewage sludge. 50 $\mathrm{kg} \mathrm{N} \cdot \mathrm{ha}^{-1}$ and $41 \mathrm{~kg} \mathrm{~K} \cdot \mathrm{ha}^{-1}$ were put into the soil with the first level. The second level was doubled in relation to the first one. The mineral fertilizers were used in the form of ammonium nitrate $34 \%$ and potassium soil $(50 \% \mathrm{~K})$.

The quantity of the yield of spring rape's seeds, the content of phosphorus in them and also the content of available forms of phosphorus for the plants in the soil after the inning of the tested plant were presented in Table 1. All the composts with the participation of municipal sewage sludge increased the yield of spring rape's seeds essentially in relation to the control variant. The biggest yield of the spring rape's seeds in comparison with the first level of the mineral nitricpotassium fertilization was achieved in the variants with the composts from the municipal sewage sludge $(100 \%)$ without an addition of the structural - formative components as well as from municipal sewage sludge (70\%) with the addition of $10 \%$ of rye straw, wastes of urban greenery and ash of the hard coal.

The double dose of the mineral nitric-potassium fertilization, which had been put into the soil with the composts with the participation of municipal sewage sludge, caused inconsiderable (statistically irrelevant) drop of the yield of spring rape's seeds in the majority variations.

Its results show that the first level of mineral nitric-potassium fertilization with the composts with the participation of municipal sewage sludge was enough to achieve the maximum yield of the spring rape's seeds.

The content of phosphorus in the spring rape's seeds was somewhat lower in the variations with the composts, with the participation of municipal sewage sludge in relation to the control variant (without composts). It concerned the Ist as well as the IInd level of mineral nitric-potassium fertiliza- tion, which were used in comparison with the composts with the participation of municipal sewage sludge. This situation is connected with larger yields of the spring rape's seeds, which were gained under the influence of the composts with the participation of municipal sewage sludge in relation to the control variant.

The content of available forms of phosphorus for the plants in the soil after the inning of the tested plant, under the influence of composts with the participation of municipal sewage sludge, increased clearly in relation with the control variant by using the I as well as the II level of the mineral nitric-potassium fertilization. The soil with the composts with the participation of municipal sewage sludge and the double dose of the mineral nitric-potassium fertilization included on average more available forms of phosphorus for the plants. The obtained results show that the organic compound of phosphorus, which were contained in the composts with participation of municipal sewage sludge, were decomposed in the mineralization process and then they moved into the available forms for the plants.

In 2003 the second laboratory experiment was carried out in the plastic columns about $10 \mathrm{~cm}$ in diameter. The soil was sifted with the sieve, which was $5 \mathrm{~mm}$ in diameter of the mesh. Then the soil was inserted into the columns in the quantity of 3 kilos per each column. The thickness of the soil was $25 \mathrm{~cm}$ in the columns. The brown incomplete soil of the 5 complex (rye good) was used in this experiment. The soil had the mechanical composition of light loam. The soil was characterized by $\mathrm{pH}_{\mathrm{KCl}} 6,1$, the content of the organic coal $8,44 \mathrm{~g} \cdot \mathrm{kg}^{-1} \mathrm{~d}$.m., the available forms of phosphorus for the plants $64,2 \mathrm{mg} \mathrm{P} \cdot \mathrm{kg}^{-1} \mathrm{~d} . \mathrm{m}$. and potassium $114,5 \mathrm{mg} \mathrm{K} \cdot \mathrm{kg}^{-1} \mathrm{~d} . \mathrm{m}$. The content of the available forms of phosphorus was an average and in the case of potassium - high.

Table 1. The effect of the sewage sludge composts and supplementary mineral nitric-potassium fertilization on the quantity of the yield of the seeds of spring rape and the content of phosphorus in them as well as the content of available forms of phosphorus for the plants in the soil after the inning of the tested plant

\begin{tabular}{|c|c|c|c|c|c|c|}
\hline \multirow[t]{3}{*}{ Type of composts } & \multicolumn{2}{|c|}{$\begin{array}{l}\text { The quantity of the yield of } \\
\text { spring rape's seed }\left(\mathrm{t} \cdot \mathrm{h} \mathrm{a}^{-1}\right)\end{array}$} & \multicolumn{2}{|c|}{$\begin{array}{l}\text { The content of phosphorus } \\
\text { in spring rape's seeds } \\
\left(\mathrm{g} \cdot \mathrm{kg}^{-1} \text { d.m. }\right)\end{array}$} & \multicolumn{2}{|c|}{$\begin{array}{l}\text { The content of the available } \\
\text { phosphorus forms in the soil after the } \\
\text { inning of the tested plant } \\
\text { (mg } \mathrm{kg}^{-1} \text { d.m.) }\end{array}$} \\
\hline & \multicolumn{6}{|c|}{ The doses of supplementary mineral nitric-potassium fertilization } \\
\hline & $\begin{array}{c}\text { Dose } \\
1\end{array}$ & $\begin{array}{c}\text { Dose } \\
\text { II }\end{array}$ & $\begin{array}{c}\text { Dose } \\
1\end{array}$ & $\begin{array}{c}\text { Dose } \\
\text { II }\end{array}$ & $\begin{array}{c}\text { Dose } \\
1\end{array}$ & $\begin{array}{c}\text { Dose } \\
\text { II }\end{array}$ \\
\hline Without compost & 1,57 & 1,18 & 9,90 & 9,50 & 85,5 & 79,9 \\
\hline Compost from sewage sludge $(100 \%)$ & 2,10 & 2,04 & 9,30 & 9,20 & 85,1 & 87,2 \\
\hline $\begin{array}{l}\text { Compost from sewage sludge }(70 \%) \\
\text { and wastes of urban greenery }(30 \%)\end{array}$ & 2,01 & 1,98 & 9,50 & 9,40 & 96,4 & 91,2 \\
\hline $\begin{array}{l}\text { Compost from sewage sludge }(70 \%) \\
\text { and rye straw }(30 \%)\end{array}$ & 1,99 & 1,93 & 9,60 & 9,40 & 95,2 & 96,9 \\
\hline $\begin{array}{l}\text { Compost from sewage sludge }(70 \%) \text {, } \\
\text { wastes of urban greenery }(15 \%) \text { and } \\
\text { rye straw }(15 \%)\end{array}$ & 1,75 & 1,95 & 9,40 & 9,40 & 90,8 & 99,5 \\
\hline $\begin{array}{l}\text { Compost from sewage s ludge }(70 \%) \text {, } \\
\text { wastes of urban greenery }(20 \%) \text { and } \\
\text { ash of the hard coal }(10 \%)\end{array}$ & 1,78 & 1,78 & 9,60 & 9,30 & 88,0 & 88,5 \\
\hline $\begin{array}{l}\text { Compost from sewage sludge }(70 \%) \text {, } \\
\text { rye straw }(20 \%) \text { and ash of the hard } \\
\text { coal }(10 \%)\end{array}$ & 1,98 & 1,92 & 9,50 & 9,00 & 87,7 & 86,4 \\
\hline $\begin{array}{l}\text { Compost from sewage sludge }(70 \%) \text {, } \\
\text { wastes of urban greenery }(10 \%) \text {, rye } \\
\text { straw }(10 \%) \text { and ash of the hard coal } \\
(10 \%)\end{array}$ & 2,09 & 1,85 & 9,60 & 9,20 & 84,9 & 85,6 \\
\hline
\end{tabular}

Composition of the composts in converting on dry mass of the individual composts

NIR for the yield of the spring rape's seeds: for factor I (the type of composts) $0,11 \mathrm{t} \cdot \mathrm{ha}^{-1}$

For factor II (the dose of mineral fertilizers NK) 0,04 ; for I $x$ II $0,16 \mathrm{t} \cdot \mathrm{ha}^{-1}$ 
There were taken into consideration two factors in the pattern of the experiment. There were four types of composts after disintegration for seven months (the composition in converting into dry mass was presented in Table 2) as the first factor and the doses of the composts without and with supplementary mineral fertilization were treated as the second factor.

The first dose of the composts (without supplementary mineral fertilization) was established on the level of the quantity of total nitrogen in the composts which amounted $0,2 \mathrm{~g} \mathrm{~N}$ per column. It amounted to the dose of $200 \mathrm{~kg}$ $\mathrm{N} \cdot \mathrm{ha}^{-1}$. An N: P: K relation was accepted in the experiment to establish the supplementary mineral fertilization against in comparison with the composts. This relation of $\mathrm{N}$ : P: K was necessary to put it into the soil with the fertilizers (the second series). This relation was established on the level of 1,0: 0,30: 0,86. The $0,2 \mathrm{~g} \mathrm{~N}$ per columns was a base of the fertilization in the variations with the composts with municipal sewage sludge (30\%) and potato pulp (30\%). Supplementary fertilization of the water solution of salt potassium $(50 \% \mathrm{~K})$ was put into these composts for the sake of the small content of potassium. The content of total potassium was accepted for the purpose to establish the doses in the variations with the composts with the $60 \%$ participation of potato pulp for the sake of the small content of nitrogen and phosphorus in relation to potassium. The dose of potassium in the form of composts was established on $0,17 \mathrm{~g} \mathrm{~K}$ level per column. This was $166 \mathrm{~g} \mathrm{~K} \cdot \mathrm{ha}^{-1}$. The deficiency of nitrogen and phosphorus in relation to the accepted dose of $0,2 \mathrm{~g} \mathrm{~N}$ per column and $0,06 \mathrm{~g} \mathrm{P}$ per column competed against the water solution of urea (46\%) and triple superphosphate $(20 \% \mathrm{P})$. The doses of the composts as well as the supplementary mineral fertilization were doubled in the third series of the experiment.

The composts were put into the soil, which was in the columns, according to the pattern of the experiment. The composts were mixed with the soil to the $7-8 \mathrm{~cm}$ depth. Then the water solutions of mineral fertilizers were put into the soil. The soil was mixed once again to the $2-$
$4 \mathrm{~cm}$ depth. The columns were placed in the room where the constant temperature of $10-15^{\circ} \mathrm{C}$ was being kept. The humidity of the soil was being kept on the $60 \%$ level of the full water humidity. The soil in the columns was being sprinkled with the redistilled water. Each object of the experiment had four repetitions. During the experiment the samples of the soil were taken from the each column of the date variant in the first day and the next after $30,60,90,120,150$, and 180 days. The average samples were made from the repetitions of each variant after drying them. Afterwards the samples were subjected to the chemical analyses.

The indication of the available forms of phosphorus for the plants was made in two repetitions. The results of the experiment were presented in Table 2.

The data in Table 2 show that the composts with potato pulp (30\%) and municipal sewage sludge (30\%), that had been put in the soil, increased the content of available forms of phosphorus for the plants in comparison with the control variant as well as with the variations of composts with the $60 \%$ participation of potato pulp. Additional application of potassium salt in the variations with the composts with potato pulp (30\%) and municipal sewage sludge $(30 \%)$ did not affect the increase of the content of the available forms of phosphorus for the plants in the soil. However, the content of available forms of phosphorus for the plants in the soil was increased by an application of the urea and triple superphosphate, additionally with the composts with the $60 \%$ participation of potato pulp. That was the effect of the available form of phosphorus, which had been put into the soil in the form of triple superphosphate.

The double doses of the composts and mineral fertilizers increased the content of the available form of phosphorus for the plants in the soil in comparison with the single doses. The soil with the compost with potato pulp $(60 \%)$ as well as urea and triple superphosphate included the more available forms of phosphorus in comparison with the soil with the compost with potato pulp (30\%)

Table 2. The changes of the content of the available phosphorus in $\mathrm{mg} \cdot \mathrm{kg}^{-1} \mathrm{~d} . \mathrm{m}$. of the soil under the influence of fertilization of the composts with the participation of municipal sewage sludge and potato pulp. The data from the experiment carried out in 2004.

\begin{tabular}{|l|c|c|c|c|c|c|c|c|}
\hline \multirow{2}{*}{ Fertilizer variation } & \multicolumn{9}{|c|}{ Time limit of marks in days } \\
\cline { 2 - 9 } & \multicolumn{1}{|c|}{0} & \multicolumn{1}{|c|}{30} & 60 & 90 & 120 & 150 & 180 & Mean \\
\hline Control & 62,2 & 60,1 & 63,6 & 62,6 & 62,5 & 62,6 & 63,0 & 62,4 \\
\hline Compost I* & 96,1 & 100,5 & 102,3 & 105,0 & 105,6 & 106,5 & 107,0 & 103,3 \\
\hline Compost II & 95,3 & 100,7 & 102,5 & 104,2 & 104,9 & 105,6 & 105,2 & 102,6 \\
\hline Compost III & 73,0 & 74,5 & 76,3 & 77,6 & 77,3 & 78,1 & 78,4 & 76,4 \\
\hline Compost IV & 72,9 & 73,7 & 75,4 & 76,2 & 76,0 & 76,8 & 77,2 & 75,4 \\
\hline Compost I + K & 96,2 & 101,0 & 102,4 & 103,1 & 108,2 & 107,8 & 107,6 & 103,7 \\
\hline Compost II + K & 96,0 & 100,5 & 102,6 & 104,1 & 105,1 & 106,0 & 106,0 & 102,9 \\
\hline Compost III + NP & 102,3 & 104,6 & 105,8 & 105,6 & 105,8 & 106,0 & 106,1 & 105,2 \\
\hline Compost IV + NP & 100,9 & 102,8 & 104,9 & 105,5 & 106,0 & 106,2 & 106,3 & 104,6 \\
\hline $\begin{array}{l}\text { Double dose of compost I } \\
\text { and K }\end{array}$ & 106,0 & 110,0 & 111,3 & 114,4 & 115,3 & 116,0 & 117,2 & 112,9 \\
\hline $\begin{array}{l}\text { Double dose of compost II } \\
\text { and K }\end{array}$ & 109,0 & 109,9 & 110,2 & 113,5 & 114,3 & 115,0 & 116,3 & 112,6 \\
\hline $\begin{array}{l}\text { Double dose of compost III } \\
\text { and NP }\end{array}$ & 119,6 & 193,0 & 120,3 & 124,0 & 122,3 & 122,5 & 124,3 & 121,7 \\
\hline $\begin{array}{l}\text { Double dose of compost IV i } \\
\text { NP }\end{array}$ & 120,0 & 120,6 & 121,6 & 120,6 & 121,3 & 122,6 & 123,6 & 121,5 \\
\hline
\end{tabular}

* Explanation of the composition of the composts:

Compost I - (potato pulp 30\%, municipal sewage sludge $30 \%$ and rye straw $40 \%$ )

Compost II - (potato pulp 30\%, municipal sewage sludge $30 \%$ and sawdust from the conifers $40 \%$ )

Compost III - (potato pulp $60 \%$, rye straw $40 \%$ )

Compost IV - (potato pulp 60\%, sawdust from the conifers $40 \%$ ) 
and municipal sewage sludge (30\%) as well as potassium salt.

The content of the available forms of phosphorus in the soil increased as time passed by. This situation confirmed the thesis from the first experiment that over the time there was a distribution of the organic compounds, which included phosphorus in the available mineral forms for the plants.

Taking into consideration the content of the available forms of phosphorus in the soil at the moment of the beginning and the end of the experiment, it could be said that intensive distribution of the organic compounds, including this element that was in the soil with the composts with potato pulp (30\%) and municipal sewage sludge $(30 \%)$ in comparison with the compost with the $60 \%$ participation of potato pulp.

The obtained results confirm the researches of Baran et al., ${ }^{1,2}$, Czekała ${ }^{3,4}$, Hermann $^{\mathbf{8}}$, Krzywy et al. ${ }^{\mathbf{1 1}}$, Siuta and Wasiak $^{\mathbf{1 7}}$, Urbaniak ${ }^{\mathbf{1 8}}$ as well as Wołoszyk ${ }^{19}$ which are pointing to the positive effect of the composts with the participation of municipal sewage sludge on the fertility and productivity of the soil.

\section{CONCLUSIONS}

1. The composts with the participation of municipal sewage sludge increased the yield of spring rape's seeds essentially, in comparison with the control variant. The double dose of the mineral nitric-potassium fertilization against the background of the composts did not have an influence on the quantity of the yield of spring rape's seeds essentially, in comparison with the single doses.

2. The composts with the participation of municipal sewage sludge after the inning of the tested plant (the first experiment) caused an increase of the available forms of phosphorus for the plants essentially. The same situation occurred in the second laboratory experiment.

3 . In the laboratory experiment the composts with participation of municipal sewage sludge (30\%) and potato pulp $(30 \%)$ increased the content of the available forms of phosphorus in the soil in comparison with the composts with $60 \%$ of participation of potato pulp, significantly.

4. Doubling the doses of the composts as well as mineral fertilizers in the laboratory experiment caused an essential increase of the content of the available forms of phosphorus in the soil.

5. The content of the available forms of phosphorus for the plants in the soil, which had been fertilized with the compost in the second experiment, increased over the time with their distribution.

\section{LITERATURE CITED}

(1) Baran S., Flis - Bujak M., Turski R., Żukowska G.: Przemiany substancji organicznej w glebie lekkiej użyźnionej osadem ściekowym. Zesz. Prob. Post. Nauk Rol., 1993, 409: $243-250$.

(2) Baran S., Szczepanowska I., Saadi L.: Wpływ użyźnienia osadem ściekowym o różnym stopniu przetworzenia na zawartość form azotu w glebie lekkiej, Fol. Univ. Stetinensis, 200 Agricultura, 1999, (77): 15 - 20.

(3) Czekała J.: Osady ściekowe źródłem materii organicznej i składników pokarmowych, Fol. Univ. Stetinensis, 200 Agricultura, 1999, (77): 33 - 38.
(4) Czekała J.: Wartość próchniczotwórcza i działanie nawozowe osadu ściekowego, Fol. Univ. Stetinensis 211 Agricultura, 2000, (84): 75 - 80.

(5) Goliński P.: Produkcyjne i ekologiczne uwarunkowania wapnowania gleb pod użytkami zielonymi. Nawozy i nawożenie, 2006, 2(27): 86 - 123.

(6) Gosek S.: Regionalne zróżnicowanie bilansu zawartości przyswajalnego potasu i magnezu w glebach Polski. Prace Naukowe Akademii Ekonomicznej we Wrocławiu, 2001, 888: $80-85$

(7) Grzebisz W., Diatta J. B., Szczepaniak W.: Produkcja i ekologiczne uwarunkowania wapnowania gleb gruntów ornych. Nawozy i nawożenie, 2006, (2) 27: 69 - 85.

(8) Hermann J.: Problemy mikrobiologicznego skażenia gleby osadami ściekowymi, Ekologia i Technika, 1994, 6 (12): $29-30$.

(9) Krzywy E. Ciubak J.: Problemy nawożenia gleb i roślin w świetle zachodzących przemian społeczno-gospodarczych w Polsce. Pol. Tow. Inż. Ekologicznej Oddział Szczeciński, 2006, 5 - 11.

(10) Krzywy E., Krzywy J.: Skład chemiczny odpadów ziemniaczanych i osadów ściekowych $\mathrm{w}$ aspekcie możliwości wykorzystania ich do celów nawozowych. Zesz. Prob. Post. Nauk Rol., 2003, 494: 233 - 239.

(11) Krzywy E., Wołoszyk Cz., Iżewska A.: Wartość nawozowa komunalnych osadów ściekowych. Oddział Szczeciński PTIE, 2000, 5 - 58.

(12) Krzywy J., Krzywy E.: Wpływ nawozów wieloskładnikowych oraz odpadu przemysłowego zawierającego siarkę i żelazo na niektóre cechy żyzności gleby. Bioremediacja Gruntów. Politechnika Śląska. Gliwice, 2002, $225-230$.

(13) Maćkowiak Cz.: Skład chemiczny osadów ściekowych i ich wartość nawozowa. Przegląd komunalny nr 1 . Wydaw. Abrys, Poznań, 2000, 7 - 8.

(14) Ostrowska A., Gawliński S., Szczubiałka Z.: Metody analizy i oceny właściwości gleb i roślin. Instytut Ochrony Środowiska, Warszawa, 1999, ss. 364.

(15) Panak H.: Przewodnik metodyczny do ćwiczeń z chemii rolnej, Wydaw. ART. Olsztyn., 1995, ss: 186.

(16) Rozwadowski P., Kałuża L., Ginalski S.: Przemysł nawozów mineralnych. Pol. Tow. Inż. Ekologicznej Oddział Szczeciński, 2006, 29 - 50.

(17) Siuta J., Wasiak G.: Zasady wykorzystania osadów ściekowych na cele nieprzemysłowe (przyrodnicze), PTIE Warszawa nr 3, 2001, 13 - 42.

(18) Urbaniak M.: Możliwość wykorzystania osadów ze ścieków komunalnych. Wyd. Ekoinżynieria, 1997, 58 - 64.

(19) Wołoszyk Cz.:Agrochemiczna ocena nawożenia kompostami z komunalnych osadów ściekowych i odpadami przemysłowymi. Wydawnictwo AR w Szczecinie 2003. Rozprawa 217, 2003, ss120. 